\title{
For science and for the Pope-king: writing the history of the exact sciences in nineteenth-century Rome
}

\author{
MASSIMO MAZZOTTI*
}

\begin{abstract}
This paper analyses the contents and the style of the Bullettino di bibliografia e di storia delle scienze matematiche e fisiche (1868-1887), the first journal entirely devoted to the history of mathematics. It is argued that its innovative and controversial methodological approach cannot be properly understood without considering the cultural conditions in which the journal was conceived and realized. The style of the Bullettino was far from being the mere outcome of the eccentric personality of its editor, Prince Baldassarre Boncompagni. Rather, it reflected in many ways, at the level of historiography of science, the struggle of the official Roman Catholic culture against the growing secularization of knowledge and society.
\end{abstract}

While history of mathematics was a well-established discipline by the mid-nineteenth century, no periodical which was entirely devoted to such a discipline existed until 1868 . By then, history of mathematics had been the subject of monographic studies, of erudite articles to be included in scientific journals and of memoirs to be included in the acts of scientific academies. An attempt to establish a specific periodical where historians of the exact sciences could publish their work was made by the French mathematician Orly Terquem (1782-1862), director of the Nouvelles annales des mathématiques. From 1855 to 1862, the Nouvelles annales included a supplement entitled Bulletin de bibliographie, d'histoire et de géographie mathématiques, which provided information relative to episodes in the history of mathematics. ${ }^{1}$ However, the dimension of the supplement was rather limited, and its contents were little more than a collection of historical curiosities, which is why historians such as George Sarton have described the Bulletin as scarcely an interesting publication. ${ }^{2}$ In 1868 a journal began to be printed which was unprecedented for its remarkable scope, its scientific rigour and its international group of collaborators.

* Dibner Institute for the History of Science and Technology, MIT E56-100, Cambridge, MA 02139, USA. I thank David Bloor, John Fauvel, John Henry, Ludovica Serratrice, and the anonymous referees for advice and assistance. Research for this paper was made possible through the support of the Dibner Institute and the resources of the Burndy Library. All translations from non-English sources, unless otherwise indicated, are my own.

1 Terquem's Bulletin was published as supplement to Volumes 14 to 20 of the first series of the Annales (1855-61), and to the first volume of the Second Series (1862). The Annales were published in Paris by MalletBachelier.

2 G. Sarton, 'Bibliographie synthétique des revues et des collections de livres', Isis (1914-1919), 2, 125-61, 133. 
Its title was Bullettino di bibliografia e di storia delle scienze matematiche e fisiche, and it was to be remembered as 'the first major journal devoted to the history of mathematics'. ${ }^{3}$ It may come as a surprise that it was published in Rome, at that time the capital of the ultra-conservative State of the Church, over which Pope Pius IX (r. 1846-78) ruled as an absolute temporal sovereign. In fact, mid-nineteenth century Rome was far from being a leading centre of mathematical research. Its cultural environment has been convincingly described as one hardly favourable to up-to-date literary and philosophical production, let alone advanced scientific research. The Bullettino was exceptional in many respects, beginning with the very fact that it was conceived and published in the Rome of the last Pope-king.

Two main issues will be addressed in the present study. The first is the general methodology adopted by those who contributed to the Bullettino. Understanding this should help to make sense of the many peculiarities of the Bullettino, which are to be found in both its contents and its format. We shall see that the journal presented a consistent and paradigmatic example of the general approach to history that came to be known as 'positivistic historiography', a methodology based on the centrality of the documents and on the scrupulous analysis of data and sources. Underlying this new attention to data collection was an awareness of the mass of archival material still to be studied, and the basic belief that 'the documents' would reveal 'the facts'.

The second issue addressed in this study is an assessment of the socio-cultural situation in which the editorial enterprise of the Bullettino was conceived and realized. I shall argue that the emergence of the new, 'scientific' historiographical methodology, through which history of science was fully legitimated as a truly scientific discipline, can be properly understood only by evaluating the socio-cultural context of its production. That the 'positivistic' methodology promoted by the Bullettino was particularly successful in the Rome of the last Pope-king was indeed far from being a coincidence.

\section{A Roman prince's dream}

Much has been written on the claustrophobic cultural atmosphere of the years preceding the end of the temporal power of the Church of Rome (1870). 'Books are not stuff for Christians', a priest declaims in a sarcastic sonnet by Roman poet Gioacchino Belli. Similarly, Giacomo Leopardi wrote about 'Rome, where nothing is understood apart from stones'. 'Editorial activity', remarked Domenico Gnoli, referring to the middle of the century, 'was forbidden rather than controlled'; there existed indeed 'a preventive censorship that was both ecclesiastical and political' ${ }^{5}$ Exceptional, in this respect, were the highly specialized and remarkably expensive archaeological publications, which continued

3 I. Grattan-Guinness, 'Talepiece: the history of mathematics and its own history', in Companion Encyclopaedia of the History and Philosophy of the Mathematical Sciences I. Grattan-Guinness (ed.), 2 vols., London, 1997, ii, 1667.

4 Quoted in F. Barberi, 'Libri e stampatori nella Roma dei papi', Studi romani (1965), 13, 433-56, 454.

5 D. Gnoli, I poeti della scuola romana (1850-1870), Bari, 1913, 6. 
to flourish even in this period. On the other hand, the state of studies on modern literature, history and the sciences has been defined as 'squalid'. ${ }^{6}$

It was in such an unpromising environment that the Bullettino first appeared in 1868. By the time the publication ended, in 1887, twenty massive quarto volumes had been completed, for a total of more than thirteen thousand pages. The methodological novelties of this periodical and its substantial contribution to the historiography of the exact sciences make it interesting not only to historians of scientific publishing but also to those working in the history of scientific knowledge tout court. Let us approach the Bullettino by describing the singular figure of its founder, financier and editor, Baldassarre Boncompagni Ludovisi, Prince of Piombino (1821-94).

Boncompagni was born into one of the wealthiest and most eminent Roman families, ennobled in 1572 when one of its members was made Pope as Gregorius XIII. He studied under the guidance of some well-known men of science, such as Abbé Barnaba Tortolini (1808-74), professor of calcolo sublime (higher calculus) at La Sapienza University in Rome, and the Jesuit astronomer Ignazio Calandrelli (1792-1866). Abbé Tortolini, author of a number of memoirs and of a textbook of calculus (1844), was the most prominent mathematician active in Rome in the middle of the century. ${ }^{7}$ In 1850 he founded the journal Annali di scienze matematiche e fisiche, and it is from a transformation of this periodical that, in 1858, the prestigious Annali di matematica pura e applicata was born. ${ }^{8}$

In 1840, while studying mathematics, Boncompagni began to collaborate with the literary journal Giornale arcadico di scienze, lettere e arti, publishing the biographical notes of the Jesuit astronomer Giuseppe Calandrelli (1749-1827) and of his assistant Andrea Conti (1777-1840). In 1843, Boncompagni's first study appeared, in a prestigious journal of mathematics, the Journal für die reine und angewandte Mathematik, directed by August Leopold Crelle. It was a dense memoir on definite integrals; in fact, it remained

6 Barberi, op. cit. (4), 454. Barberi remarks that in Rome 800 new works were published between 1835 and 1844, while 4900 were published in Milan, 3300 in Venice, 2300 in Turin, 1700 in Naples and 1350 in Florence. Similarly, in the periodical sector, the inferiority of Rome with respect to the northern Italian towns was clear. On the periodical press in Rome in this period see also O. Majolo Molinari, La stampa periodica romana dell'Ottocento, 2 vols., Rome, 1963.

7 B. Tortolini, Elementi di calcolo infinitesimale, Rome, 1844. The indication 'Volume 1: differential calculus' is added, but no other volumes followed it. Tortolini wrote on the foundations of calculus, on the applications of calculus to geometry and on problems of mathematical physics. He showed particular interest in expanding the application of Cauchy's methods for the integration of differential equations. Tortolini began teaching calculus at La Sapienza in 1837, in 1846 he was also teaching mathematical physics at the Seminario Romano and in 1856 he added to these duties the direction of the printing office of the Propaganda Fide. As for his ecclesiastical career, in 1866 he became canonico titolare of the Basilica of Santa Maria ad Martyres (hence the title of 'Monsignore'). On Tortolini's life and religious activity see V. Diorio, 'Cenni intorno alla vita ed ai lavori di monsignore D. Barnaba Tortolini', Atti dell'Accademia Pontificia de' Nuovi Lincei (1875), 28, 93-106, which includes a complete list of Tortolini's memoirs.

8 Tortolini's annali ceased publication in 1857. In 1858 Tortolini became one of the four editors of a new journal, the Annali di matematica pura e applicata, together with Enrico Betti in Pisa, Francesco Brioschi in Pavia and Angelo Genocchi in Turin. The foundation of the new journal provided recognition and legitimation to the 'Italian school' of mathematics. The journal was conceived as the instrument with which to establish fruitful relations with the most advanced European schools, primarily the German school. On the deeply political programme of the new journal, and the less than enthusiastic participation of Tortolini to the enterprise, see U. Bottazzini, Va' pensiero: immagini della matematica nell'Italia dell'Ottocento, Bologna, 1994, 124-7. 


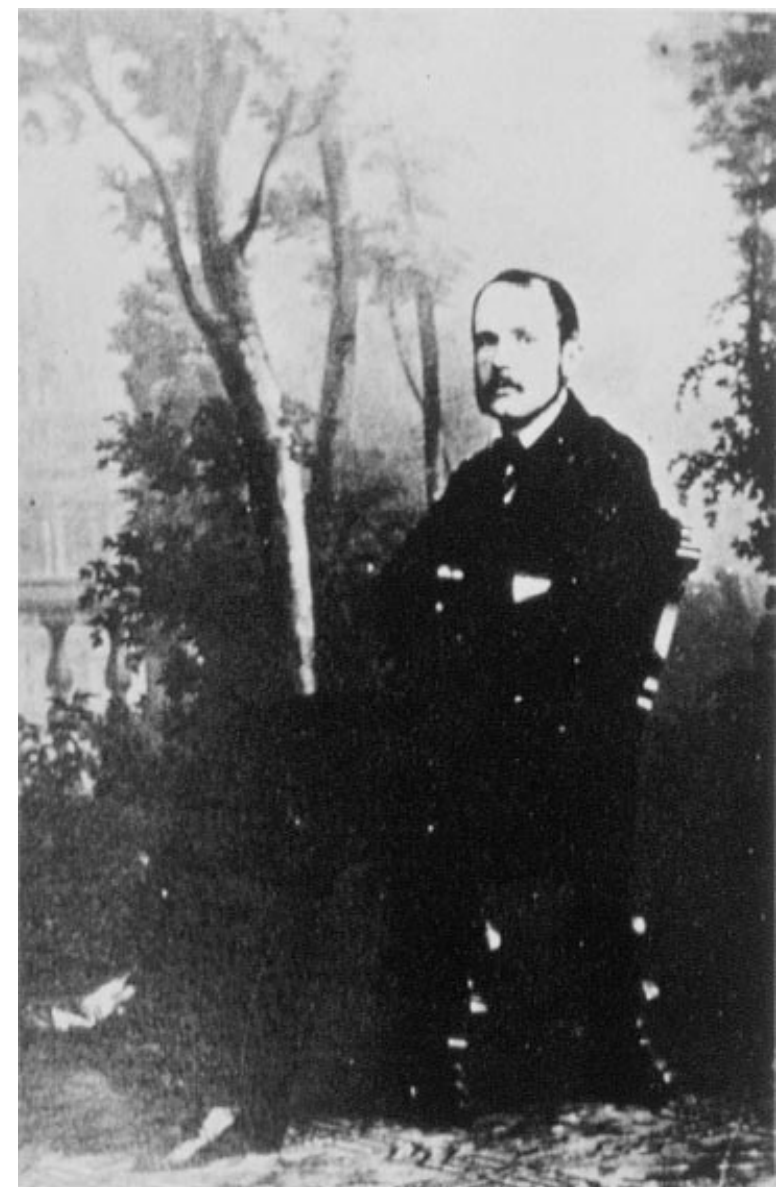

Figure 1. Baldassarre Boncompagni (1821-94).

his most significant contribution to mathematical research. ${ }^{9}$ After the mid-1840s Boncompagni's interest decidedly shifted towards the history of the exact sciences, and in 1846 he published an essay ' On some advancements of physics in Italy in the sixteenth and seventeenth centuries'.$^{10}$ Here Boncompagni argued for the importance of studying the history of scientific knowledge, 'as it is not less important to know about the state of scientific studies in different times and in different countries' than to know about political and literary history. 'The history of sciences', he argued, following Francis Bacon, 'is the eye of the history of the world'.

From around 1850 Boncompagni's publications were to be mostly devoted to reconstructing the chronology and the channels of the transmission of mathematical knowledge from the Arabic world to Christian Europe. Such research was articulated in

9 B. Boncompagni, 'Recherches sur les intégrales définies', Journal für die reine und angewandte Mathematik (1843), 25, 74-96.

10 B. Boncompagni, 'Intorno ad alcuni avanzamenti della fisica in Italia nei secoli XVI e XVII', Giornale arcadico di scienze, lettere ed arti (1846), 109, 3-48. 
a number of meticulous studies on scarcely known translators and mathematical practitioners who were active in Italy in the twelfth and thirteenth centuries, such as Guido Bonatti, Platone Tiburtino, Gherardo da Cremona, and Gherardo da Sabbioneta. Boncompagni addressed a number of questions about the chronology of their works, their biographical data and their specific contributions to the mathematical sciences. ${ }^{11}$ But it was Boncompagni's essay (1851-2) on Leonardo Pisano, also known as Fibonacci, that earned him the admiration of those working in the history of the exact sciences. Not only did Boncompagni carefully reconstruct the biography of this hitherto obscure figure, but he also assessed his scientific role in all its historical relevance. ${ }^{12}$

In addition to his personal contributions, Boncompagni acted as a supporter and financier of studies in the history of the mathematical sciences. It has been correctly remarked that his role went well beyond that of a patron, and that he rather acted as a 'cultural organizer'. ${ }^{13}$ The main objectives of Boncompagni seem to have been to further the diffusion of the study of medieval mathematics and, as we shall see, to support the pontifical cultural institutions. A crucial instrument of this ambitious project was the Tipografia delle Scienze Matematiche e Fisiche (Printing Office of the Mathematical and Physical Sciences), founded by Boncompagni around $1850 .{ }^{14}$ In this printing office historical and scientific essays were published, and also a number of scientific correspondences, bibliographies and transcriptions of medieval manuscripts. ${ }^{15}$ Among the periodicals which were published by Boncompagni were not only the Bullettino but also, from 1871, the Atti dell'Accademia Pontificia dei Nuovi Lincei (Acts of the Pontifical Academy of the New Lincei), official organ of the scientific culture of the Vatican, and the Bullettino metereologico, periodical of the observatory of the Collegio Romano, edited by the Jesuit Angelo Secchi.

In addition to this publishing activity, Boncompagni assembled a remarkable library specializing in the history of the exact sciences. The library reached the size of around

11 B. Boncompagni, Della vita e delle opere di Guido Bonatti, astrologo e astronomo del secolo decimoterzo, Rome, 1851; idem, 'Delle versioni fatte da Platone Tiburtino, traduttore del secolo duodecimo', Atti dell'Accademia Pontificia dei Nuovi Lincei (1850-1), 4, 247-86; idem, 'Della vita e delle opere di Gherardo Cremonese, traduttore del secolo decimo secondo, e di Gherardo da Sabbioneta, astronomo del secolo decimoterzo', ibid. 387-493.

12 B. Boncompagni, 'Della vita e delle opere di Leonardo Pisano, matematico del secolo decimoterzo', Atti dell'Accademia Pontificia dei Nuovi lincei (1851-2), 5, 208-45. Boncompagni also edited Leonardo Pisano's writings; see B. Boncompagni (ed.), Opuscoli di Leonardo Pisano, Florence, 1856; and idem (ed.), Scritti di Leonardo Pisano, matematico, 2 vols., Rome, 1857-62 (the first volume contains the Liber Abbaci, the second the Practica Geometriae and other minor essays). This last work was published by the Tipografia delle Scienze Matematiche e Fisiche, founded by Boncompagni. For a presentation of the main achievements of Boncompagni's medieval studies, and for a contextualization of his work with respect to contemporary European scholarship, see G. Codazza, 'Il principe Boncompagni e la storia delle scienze matematiche in Italia', Il politecnico (1864), 91, $5-27$.

13 Chiara Lefons, 'Un capitolo dimenticato della storia delle scienze in Italia: il Bullettino di bibliografia e di storia delle scienze matematiche e fisiche di Baldassarre Boncompagni', Giornale critico della filosofia italiana (1984), 63, 65-90, 74.

14 See Vincenzo Cappelletti, 'Baldassarre Boncompagni', in Dizionario biografico degli italiani, Rome, 1969.

15 In addition to Boncompagni's work, in this printing office such works were published as medieval treatises of arithmetic (1857), unpublished works and letters by Pietro Cossali (1857) and a magnificent edition in ottavo grande of La composizione del mondo, by Ristoro d'Arezzo (1859). 
twenty thousand volumes and six hundred manuscripts. ${ }^{16}$ Its strength was in the collection of medieval abbaci and early treatises of arithmetic, but it also included texts on the natural sciences, archaeology and history, and contained a rich theological section. The assembling of the library was made possible by a network of Boncompagni's correspondents, which covered the whole of Europe. Upon receiving information of the presence of an interesting book or manuscript, Boncompagni would send one of his many secretaries to purchase the piece or, when this was impossible, to realize a facsimile. The collection was intended primarily as an instrument to reconstruct the complex modalities of the transmission of mathematical knowledge from the Arabic world to Christian Europe, and it was constantly open to scholars from every country.

The foundation of the Bullettino was another step in Boncompagni's cultural project. The periodical was designed to provide a space where complete studies, work-in-progress pieces, notes, letters and discussions could be published, providing a specific forum for the scattered community of the historians of the exact sciences. From the very beginning the Bullettino was an authoritative and highly international journal, with contributions from many of the most eminent historians of mathematics of the period: the Germans Moritz Cantor, Maximilian Curtze, Sigmund Günther and Hermann Hankel; the Belgian Paul Mansion; the Frenchman Charles Henry; the Dutchman David Bierens de Haan, and the Italians Antonio Favaro, Angelo Genocchi, Domenico Chelini and Pietro Riccardi. Wellknown orientalists such as Louis Sedillot and Moritz Steinschneider also offered contributions. Boncompagni was assisted in the direction by strict collaborators such as Enrico Narducci, Timoteo Bertelli and Ferdinando Jacoli. Articles appeared in Italian and French, rarely in Latin; German, Dutch, Swedish and Russian contributions were translated. A yearly volume included up to ten memoirs, and a variable number of notes, reviews and abstracts, concluded by a section where new publications in the field were listed. Boncompagni contributed with fifty-five memoirs and seventy-seven 'notes' in which he critically analysed pieces by other contributors. In fact, he personally edited almost any piece published in the Bullettino. Boncompagni invited the contributors to strictly follow guidelines derived from the methodology of the philological and palaeographic sciences. ${ }^{17}$ This meant that great attention was paid to the handling of the original sources, which had to be carefully reconstructed, transcribed (often the facsimile was published) and integrated with a massive apparatus of references. Characteristic was the way in which reference and quotations were given. Following the erudite tradition of philological and humanistic studies, Boncompagni asked contributors to render always the complete front page as title, including indications of the line breaks, and to list every

16 In his last years, Boncompagni contacted both the city council of Rome and the Vatican Library in order to find an appropriate collocation for his library. A series of minutiae prolonged the negotiations until suddenly the prince died, in 1894. Four years later the heirs dispersed the collection. On Boncompagni's library see E. Narducci, Catalogo di manoscritti ora posseduti da don B. Boncompagni, Rome, 1862; idem, Catalogo di edizioni del secolo XV possedute da D. Baldassarre Boncompagni, Rome, 1893; Catalogo della insigne biblioteca appartenuta alla chiara memoria del Principe D. Baldassarre Boncompagni, 2 vols., Rome, 1895-6; and the impressive catalogue of the 1898 sale: Catalogo della biblioteca Boncompagni, 6 vols., Rome, 1898.

17 See A. Favaro, 'Don Baldassarre Boncompagni e la storia delle scienze matematiche e fisiche', Atti del Regio Istituto Veneto di Scienze, Lettere ed Arti (1894-5), 6, 509-21, 514. 


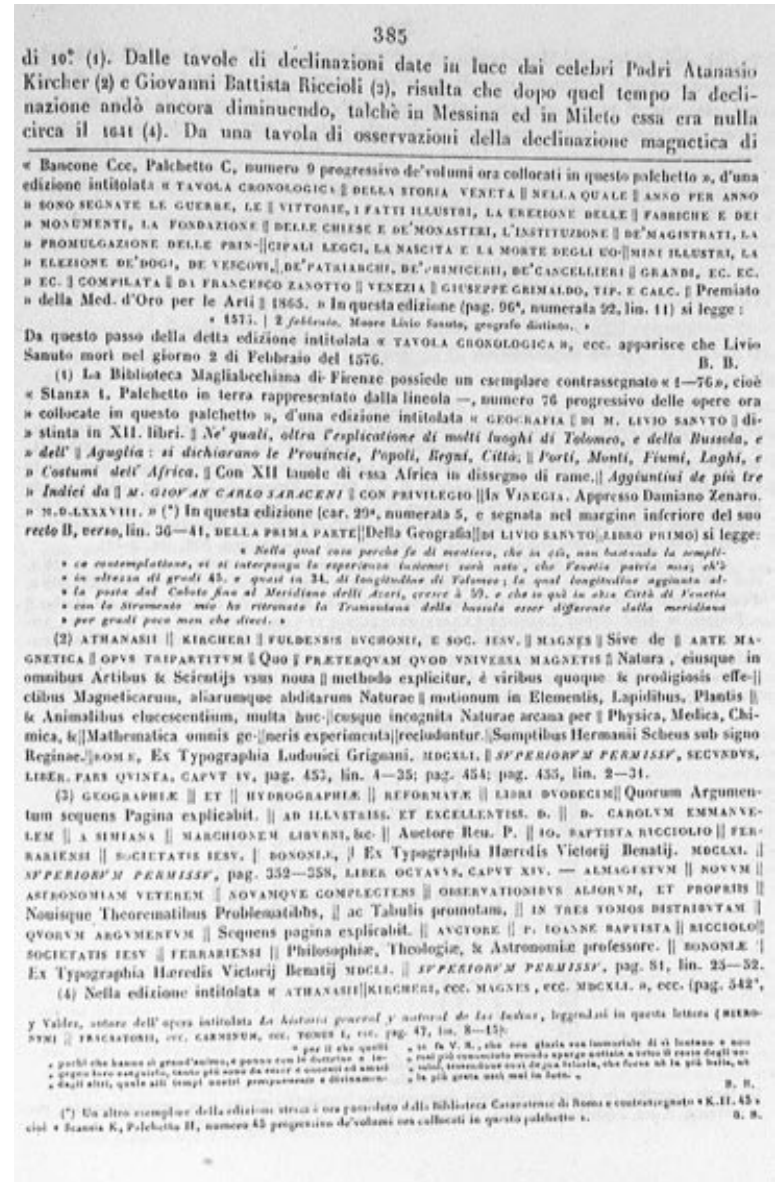

Figure 2. The Bulletino's notorious footnotes (from Volume 1, 1868).

edition of a given book or every known copy of a given manuscript as well as the libraries where these exemplars could be found. This unusual attention to the philological study of the original sources had already characterized Boncompagni's early essays, and it was now to shape the entire production of the Bullettino. ${ }^{18}$

It is in relation to the unusual degree of formal accuracy displayed by the editor of the Bullettino that anecdotes about the 'exaggerations' of the Roman prince began to circulate. Collaborators such as Moritz Cantor and Paul Mansion commented on the

18 It should be noted that the philological methodology that inspired Boncompagni can be considered an 'old' model, one centred on text revival and restoration, and as such one proper of classical philologists and humanistic scholars. 'Modern' philology, which emerged at the end of the eighteenth century, was characterized instead by a new conception of 'interpretation', i.e. the historical understanding of cultures through textual analysis. For the traditional methodology see D. Kelley, The Foundations of Modern Historical Scholarship, New York, 1970, 53-86. On the origins of the 'modern' methodology, see R. Leventhal, 'The emergence of philological discourse in the German States, 1770-1810', Isis (1986), 77, 243-60. 
erudition of Boncompagni and on the richness of his overlong footnotes. ${ }^{19}$ George Sarton was clearly drawing on this when he underlined 'the extreme exactness of the prince', one negative consequence of which was that 'the prince used to interrupt the printing of his journal in order to make further corrections in the remaining copies! As a result, there are numerous differences among the copies of the Bullettino that are spread around the world ' ${ }^{20}$ In Italy, such a judgement was echoed in Aldo Mieli's bibliographical essay on the history of science (1916), where the application of the rules of diplomatic transcription to the history of science is defined as 'pedantic'. ${ }^{21}$ In 1923, writing about the life of the prince, an Italian biographer concluded, 'famous collector of mathematical books, cultivator of the history of the mathematical and physical sciences, very diligent bibliographer, indeed a too diligent one, as in his later years such a diligence reached the most bizarre excesses'. ${ }^{22}$ Gino Loria, in his important 1946 essay on the historiography of mathematics, recommended reading the Bullettino on the ground that there modern historiographical methods 'reached the highest degree of rigour and precision'. But at the same time he noted that such precision was excessive. To have an idea of Boncompagni's methods, Loria wrote, one should read his memoir on Smeraldo Borghetti, author of a medieval treatise on arithmetic:

It is a 284-page work, entirely devoted to a scientist so insignificant that, even after the enormous effort of the excellent bibliographer, historians (such as Cantor, for instance) do not mention him at all. In this piece one finds the biographical data of every author being cited, and they are derived from different sources; every citation includes a complete transcription of the title, every single edition of the main works is described, and libraries where copies can be found are listed.

'As a consequence', Loria continues, 'footnotes are not an appendix to the text, but rather the most essential part of it'. Boncompagni's remarkable efforts seemed not to be justified by the final result; rather, Loria noted, 'they look like sportive manifestations, the goal of which is to strengthen the muscles', or like those laboratory experiments which are not relevant in themselves but designed to train young scientists. Loria concluded by noting that Boncompagni's work proved to be a remarkable source of inspiration for the following generation of historians, who improved on it by directing their attention to more relevant historical figures, and by reducing to the essential the apparatus of notes and quotations. $^{23}$

Even in the most recent literature Boncompagni's work is given an ambivalent judgement: on the one hand its innovative nature is acknowledged, but on the other the

19 M. Cantor, 'Fürst Baldassarre Boncompagni Ludovisi. Ein Nachruf', Zeitschrift für Mathematik und Physik (1894), 39, 201-3; P. Mansion, note in Revue des questiones scientifiques (1894), 6, 242.

20 'Le prince interrompit le tirage de sa revue pour apporter encore des corrections dans les exemplaires restant à tirer! Il en résulte d'assez nombreuses differences entre les divers exemplaires $d u$ Bullettino qui sont éparpillés dans le monde'. G. Sarton, 'Bibliographie synthétique des revues et des collections de livres', Isis (1914-19), 2, 133.

21 A. Mieli, La storia della scienza in Italia. Saggio di bibliografia e di storia della scienza, Florence, 1916, 57. 22 G. Fumagalli, La bibliografia, Rome, 1923, p. xxi.

23 Quotations from G. Loria, Guida allo studio della storia delle matematiche. Generalità, bibliografia, Milan, 1946, 74-6. The memoir Loria is referring to is B. Boncompagni, 'Intorno ad un trattato di aritmetica del P. D. Smeraldo Borghetti Lucchese, canonico regolare della Congregazione del SS. Salvatore', Bullettino (1880), 13, $1-80,121-200,245-368$. 
excessive attention paid to formal issues and to secondary figures in the history of science is underlined. So, for instance, Ivor Grattan-Guinness defines the Bullettino as the first important journal in the history of mathematics and recognizes that 'its twenty annual volumes contain a mass of invaluable research, especially for the Renaissance period', but he also refers to Boncompagni as 'a rich prince able to indulge his eccentricities, he even changed text while passing proofs (so that not all copies are the same), and insisted on authors indicating line-breaks when rendering titles of works!'. ${ }^{24}$ Once again, the overly meticulous and indiscriminate use of the methodological instruments of philology and palaeography is recognized as the main characterizing aspect of Boncompagni's work. Once again, the explanation for the general methodology of the studies published in the Bullettino is found in the eccentric personality of its founder, in his maniacal precision. But, I suggest, this is not a satisfactory historical explanation for a complex phenomenon such as the Bullettino. It is precisely this 'style', this minuzionsaggine (minuteness) - as his collaborator Favaro called it - that should be problematized and made the object of further investigation. ${ }^{25}$ The remainder of this paper is devoted to investigating the cultural significance of such a historiographical methodology, going beyond the usual recognition of the 'eccentricity of the prince'.

\section{Contents of the Bullettino}

Let us begin with a rapid overview of the contents of the Bullettino. Most of the memoirs and notes were devoted to the medieval mathematical and physical sciences. The crucial theme was the transmission of mathematical techniques from the Arabic world to Christian Europe, which continued and expanded the original interest of Boncompagni. Indeed, the most assiduous collaborators worked on medieval science, from theories of magnetism (Timoteo Bertelli), to optics (Enrico Narducci), to the practice of astronomy and mathematics in the Arabic culture (Louis Sedillot and Moritz Steinschneider). ${ }^{26}$

Boncompagni contributed to this sector of research with notes, reviews, editions of unpublished manuscripts and various memoirs. ${ }^{27}$ Remarkable is the space devoted to

24 I. Grattan-Guinness, op. cit. (3), ii, 1667.

25 Favaro, op. cit. (17), 514.

26 See T. Bertelli, 'Sopra Pietro Peregrino di Maricourt e la sua Epistola de magnete', Bullettino (1868), 1, 1-32; idem, 'Intorno a due codici vaticani della Epistola de magnete di Pietro Peregrino di Maricourt, ed alle prime osservazioni della declinazione magnetica. Nota', Bullettino (1871), 4, 303-31; E. Narducci, 'Intorno ad una traduzione italiana, fatta nel secolo decimoquarto, del trattato d'Ottica di Alhazen, matematico del secolo undecimo, e ad altri lavori di questo scienziato', Bullettino (1871), 4, 1-48; idem, 'Intorno al Tractatus Spherae di Bartolomeo da Parma, astronomo del secolo XIII, e ad altri scritti del medesimo autore', Bullettino (1884), 17, 1-31; L. Sedillot, 'De l'École de Bagdad et des travaux scientifiques des Arabes. Lettre a B. Boncompagni', Bullettino (1868), 1, 217-22; idem, 'Sur les emprunts que nous avons faits à la science arabe, et en particulier de la determination de la troisième inégalité lunaire ou variation, par Aboul-Wéfa da Bagdad, astronome du Xme siècle. Lettre a B. Boncompagni', Bullettino (1875), 8, 63-78; M. Steinschneider, 'Études sur Zarkali, astronome arabe du XIme siècle, et ses ouvrages', Bullettino (1881), 14, 171-82; (1883), 16, 493-513; (1884), 17, 765-94; (1885), 18, 343-60; (1887), 20, 1-36, 575-604; idem, 'Aven Natan e le teorie sulla origine della luce lunare e delle stelle presso gli autori ebrei del medio evo', Bullettino, (1868), 1, 33-40.

27 See, for instance, B. Boncompagni, 'Intorno al Tractatus proportionum di Alberto di Sassonia', Bullettino (1871), 4, 470-92; idem, 'Intorno al Tractatus de abaco di Gerlando', Bullettino (1877), 10, 648-56; idem, 'Intorno ad uno scritto inedito di Adelardo di Bath intitolato Regule abaci', Bullettino (1881), 14, 1-90. 
oriental mathematics, an area dominated by French and German orientalists. ${ }^{28}$ By comparison, very little space was devoted to Greek mathematics, and such attention as was given went mostly to texts such as Euclid's Elements - texts that were to play a major role in the following ages. ${ }^{29} \mathrm{~A}$ second theme to which remarkable space was devoted was Galileo's work. The interest in Galileo increased as did the influence of Antonio Favaro (1847-1922) on the Bullettino. A professor of mathematics and engineering at the University of Padua, Favaro offered, in 1878, the first course of history of mathematics ever given in Italy. According to Favaro, 'without history no science is complete', given that history provides scientists with 'a survey of the means employed and the ways followed to enrich scientific knowledge through fruitful discovery' and that this is extremely useful to future discoverers. History is also important as preliminary to the teaching of the sciences: the 'historical method' is indeed 'a powerful instrument in the hands of the teacher', and 'without history no didactical method will give the good results which should be expected'. On the other hand Favaro was convinced, like Boncompagni, that 'the history of the sciences in general, and that of mathematics in particular, is itself a science', and as such it can be a cause of scientific enhancement. History of the exact sciences, then, is 'a field of useful and fruitful research', particularly for 'those who, in the field of mathematics, do not consider themselves creative geniuses, a rare gift indeed, and are not willing to turn themselves into calculating machines'. ${ }^{30}$ Coherently, Favaro embraced the 'positivistic' and cumulative approach to the history of science proper of the Bullettino. ${ }^{31}$ At the conclusion of its publication, Favaro devoted himself to the publication of the complete works of Galileo, an edition characterized by its remarkable completeness and philological rigour. The figure of Galileo, as reconstructed by Favaro and others in the pages of the Bullettino, played the crucial role of linking the classical and medieval tradition to modern science. It should be noted that, in the last ten years of the periodical, the rising interest in Galileo and the Galilean tradition was intertwined with the growth of nationalist motives. This component, which was absent in Boncompagni's original perspective, was in some way analogous to the contemporary debate about the nationality of Copernicus that involved a number of German historians. ${ }^{32}$

Medieval science and Galileo were the two main topics treated in the twenty-year life of the Bullettino. Their presence was clearly related to the interests of the two main contributors, Boncompagni himself and Favaro. The two lines of research were far from conflicting, though. First, medievalists and Galilean scholars shared a common historical

28 See, for instance, L. Sédillot, 'De l'astronomie et des mathématiques chez les Chinois. Lettre à B. Boncompagni', Bullettino (1868), 1, 161-6; and idem, 'Grande exécution d'automne. Lettre à M. le Dr Ferdinand Hoefer, au sujet des sciences mathématiques des Indiens, et des origines du sanskrit', Bullettino (1875), 8, 457-68.

29 See, for instance, M. Cantor, 'Euclide e il suo secolo. Saggio storico-matematico', Bullettino (1872), 5, 1-73. Boncompagni himself wrote on Euclidean commentaries of late antiquity: B. Boncompagni, 'Intorno al Commento di Proclo sul primo libro degli Elementi di Euclide', Bullettino (1874), 7, 152-65.

30 A. Favaro, 'La storia delle matematiche nella Università di Padova. Lettera del prof. A. Favaro a D. B.Boncompagni', Bullettino (1878), 11, 801.

31 Quotations from the letter Favaro wrote to Boncompagni to announce his new course, published as A. Favaro, 'La storia delle matematiche nell'Università di Padova', Bullettino (1878), 11, 799-801.

32 The Bullettino published a number of essays and notes on Copernicus. See, for instance, M. Cantor, 'Sulla nazionalità di Copernico', Bullettino (1876), 9, 701-16. 
perspective, where medieval studies were seen as preparatory to the achievements of Galileo (strengthening the image of an 'Italian tradition'). Second, both medievalists and Galilean scholars adopted the positive, descriptive methodology recommended by Boncompagni. ${ }^{33}$

In addition to such central themes, a few contributions regarded historical aspects of modern mathematical sciences, being mostly bibliographical notes. This is the context of the notes on Condorcet, Laplace, Cauchy, Lobachevski, Riemann, Plücker, Grassmann and Chasles, and on the Italians Lorenzo Mascheroni and Giovanni Plana. The Bullettino also presented scholars with a massive quantity of unpublished material. This included a number of letters by d'Alembert (they alone count for 142 pages), Galileo, Lagrange, Laplace, Euler, Gauss and Gianfrancesco Malfatti. ${ }^{34}$ The list of the unpublished pieces - around a thousand - occupies twenty heavily written quarto pages. ${ }^{35}$

\section{History of mathematics as a scientific discipline}

What image of mathematics, and of science in general, emerges from the historical material collected and meticulously described by the contributors? As in previous works by Boncompagni, neither an explicit presentation of philosophical views of knowledge is offered to the reader, nor is justification provided for the methodological approach adopted. Such issues are not simply absent, they are systematically avoided. Thus, contrary to what was already a common practice, the first number (1868) opened without any editorial preface. In fact, as noted above, the editorial line of the Bullettino was characterized by a positivistic approach to history, according to which historical understanding can only be reached through gradual accumulation of data and direct knowledge of the original sources. Consequently, priority was attributed to the scrupulous reproduction of documentary sources rather than to their interpretation, and any judgement that was not directly grounded on documents was carefully avoided. Only in this way, it was thought, could the 'truth' of the facts be definitely assessed.

Significantly, Timoteo Bertelli (1826-1905), introducing the first memoir of the first volume, asked for the constitution of an international centre of historical research, the primary goal of which should be the collection of information presently spread among European libraries. The entire historiographical enterprise comes to coincide, in his view, with an endless collection and cataloguing of historical material:

An academic institution which was specifically devoted to physico-mathematical historical studies, and which counted among its members, chosen from every town in Europe, not only different sorts of scientists, but also philologists, bibliophilists, geographers and erudite persons, could reach very soon extremely important results. And everyone agrees that science (and physics

33 For an example of such a 'nationalistic' interpretation of Boncompagni's medieval studies see Codazza, op. cit. (12).

34 See 'Dieci lettere inedite di Giuseppe Luigi Lagrange ad Antonio Maria Lorgna', Bullettino (1873), 6, 131-41, followed by a note by Boncompagni (ibid., 142-52); and 'Correspondance inédite de d'Alembert, avec Cramer, Lesage, Clairaut, Turgot, Castillon, Beguelin, etc., publiée avec notice par M. Charles Henry', Bullettino (1885), 18, 507-649.

35 See 'Indice di documenti inediti pubblicati nel presente Bullettino', Bullettino (1887), 20, 729-49. 
in particular) is very much in need of such results. This is an idea I have had in my mind for years, and I would throw myself entirely into this work, even if my contribution would only be like the small grain of the ant. ${ }^{36}$

On the Bullettino's notorious guidelines for quotations and citations, Bertelli remarked,

I hope I will be forgiven for rendering in full the authorities I refer to, instead of providing, as I could have easily done, a simple citation. I did so on purpose, in order both to spare others heavy research, and to make clearer my argument through the context.

And, on the essentially descriptive nature of his research, he noted that 'it is necessary to collect and edit the mass of unpublished documents, and to analyse more carefully those which have been already published, rather than articulating a history of the physical sciences'. ${ }^{37}$

Ferdinando Jacoli (1836-1912) encouraged his fellow historians to search 'with more attention and dedication [amore], the dusty deposits of our public libraries', in order to clarify those points in the biographies of the man of science which remain obscure (in this case it was a problem about the life of Bonaventura Cavalieri) ${ }^{38}$ In a similar spirit, Favaro hailed the recent flourishing of studies in the history of mathematics, which would allow the rediscovery of many valuable figures otherwise doomed to oblivion. The philological accuracy of his colleagues and their 'relentless' work of collection are defended by noting that only the accumulation of such 'apparently meaningless particulars' provides historians with the 'complete reconstruction' they are looking for. ${ }^{39}$ In his contribution to the last volume of the Bullettino, Favaro returned to the point by claiming that 'only such scrupulous and rigorous pieces of work make possible the collection of material to be employed in a synthetic work which faithfully represents the state of the sciences in a certain age' ${ }^{40}$ Favaro also remarked that 'each document must be cited with absolute precision, or reproduced in the most scrupulous way, and in its entire length'; indeed this is what distinguishes historically inclined mathematicians from other historians: 'they introduce into historical practice that sense of absolute rigour which is an essential part of their own studies' ${ }^{41}$

Every scholar studying the Bullettino has pointed out the lack of a 'speculative dimension' in its articles, and the evident self-limitation of the authors to a purely descriptive task, as opposed to some deeper form of analysis and understanding. Generally these 'limits' are explained by referring to a cultural shortcoming of Boncompagni himself. This is the case with Boncompagni's biographer Vincenzo Cappelletti:

Boncompagni's work, to put it briefly, was remarkable and sometimes excellent as to the philological and diplomatic erudition displayed, but this erudite moment was neither transcended in the critical understanding of what the historiography of scientific thought can and must be, nor framed in a history of culture and of ideas.

36 Bertelli, op. cit. (26), 3.

37 T. Bertelli, 'Sulla Epistola di Pietro Peregrino di Maricourt, e sopra alcuni trovati e teorie magnetiche del secolo XIII’, Bullettino (1868), 1, 65-99; 109-39; 319-420.

38 F. Jacoli, 'Notizia sconosciuta relative a Bonaventura Cavalieri', Bullettino (1869), 2, 299-312, 312.

39 A. Favaro, 'Della vita e degli scritti fisico-matematici di Ermanno Grassmann', Bullettino (1878), 11, 699-756, 699.

40 A. Favaro, review of Alfred Terquem, La science romaine à l'époque d'Auguste. Étude historique d'après Vitruve, in Bullettino (1887), 20, 385.

41 A. Favaro, 'Gli autografi galileiani nell'Archivio Marsigli in Bologna', Bullettino (1882), 15, 581-630, 581. 
Unlike Mach or Duhem, Cappelletti continues, 'Boncompagni understood science as something autonomous with respect to culture', and never thought of relating his historiographical work to 'a structural understanding of scientific knowledge'. ${ }^{42}$ This seems to be, at present, the 'standard view' on Boncompagni and his methodology. It lies, I believe, on a lack of understanding of the cultural project that originated the Bullettino.

Boncompagni insisted that the reader should be offered an objective and accurate description of the documents relative to the history of mathematics. His collaborators followed such indications, even if this meant writing extremely long bibliographical divagations and following the complex rules of diplomatic transcription. Such rules were respected even when dealing with modern documents, which is - to our eyes - plainly superfluous. As a result, reading the Bullettino is a demanding task. Why, one might wonder, such an 'unnecessary' display of erudition? To cast light upon this issue, I suggest looking at Boncompagni's basic goals, and at the context in which he was acting.

Boncompagni aimed to make the history of mathematics a legitimate scientific discipline. But let us not forget that he acted in nineteenth-century Rome, the Rome of the antiquarian culture, the archaeologists and the 'quiet erudition', 43 the Rome of the Arcadic Journal, which 'could survive....as far as it slept the sleep of the just'. ${ }^{44}$ It is Leopardi, again, who referred to Roman scholars as thinking that 'the highest point of human wisdom, if not the only human science, is antiquarianism. I still haven't met a man of letters to whom literature means something different from archaeology'. ${ }^{45}$ The literate and political man Massimo D'Azeglio offered a basic explanation for the antiquarian nature of Roman culture: 'antiquarianism was one of the few possible fields of study under the rule of the priests. It would take great ingenuity to find subversive tendencies in it'. ${ }^{46}$ Historian Sergio Negro adds that it was common for 'the enemies of the pontifical rule to say that archaeology was the only science which did not cast a shadow over ecclesiastics' ${ }^{47}$ It is a fact that the pontifical government had been favouring, through its more erudite cardinals, archaeological studies and excavations. An active Accademia Romana d'Archeologia was supported, as well as an international institute called Istituto di Corrispondenza Archeologica, which was an important centre for epigraphical research. Well-known epigraphists such as Bartolomeo Borghesi, Theodor Mommsen and Wilhelm Henzen worked at the Istituto, as did the main Roman archaeologists of the period: Luigi Canina, Carlo Ludovico Visconti and Giovanni Battista de Rossi. De Rossi, who has been described as 'the first representative of modern archaeology in Rome', was taken as an exemplar for his application of scientific rigour to archaeological research. ${ }^{48}$

Once it is made clear that the science of archaeology was the core of Roman cultural life, one can try to identify the ideological dimension of this antiquarian culture. For this purpose, it is useful to know that the leading 'scientific' archaeologist, de Rossi, was also known for being the founder of a new branch of archaeology, called 'Christian

42 Cappelletti, op. cit. (14).

43 Barberi, op. cit. (4), 453.

44 Gnoli, op. cit. (5), 6.

45 Quoted in S. Timpanaro, La filologia di Giacomo Leopardi, Florence, 1955, 94.

46 Quoted in Barbieri, op. cit. (4), 453.

47 S. Negro, Seconda Roma (1850-1870), Milan, 1943, 249.

48 Negro, op. cit. (47), 252-3. 
archaeology', which enjoyed remarkable fortune from the 1860s. A few words must be said on this new discipline, and on its cultural relevance. Traditional ('profane') archaeology had for a long time been favoured by the pontifical government. Indeed, the Roman Church considered itself as the only legitimate heir of the imperial grandeur of ancient Rome. The imperial eagle had been taken as a symbol of continuity between the 'first', classical Rome and the 'second' Rome - that of the pontiff and of his universal dominion over Christianity. The imperial ruins were therefore invested with important, self-celebrative meanings. In the last twenty years of the life of the State of the Church, and particularly after the republican insurrection which upset Rome in 1848 and 1849, the political situation of the pontifical government deteriorated rapidly, and from 1861 Rome found itself entirely surrounded by a new, aggressive political entity, the Kingdom of Italy, the anti-clerical and expansionist policy of which was all too evident. In such a climate, intellectual resources were mobilized with unprecedented vigour to defend the historical basis of the legitimacy of the temporal power of the Church. The new discipline created by de Rossi emerged in the middle of this struggle as a credible and rigorous scientific discipline and, at the same time, as a powerful apologetic weapon to be used against religious indifference and against the arguments put forward by the protestant churches. As Negro noted, 'much of the flourishing of this science was due to the way it could be used in religious demonstrations'. ${ }^{49}$ So, for instance, this archaeological discipline could provide 'proofs' of the fact that certain Catholic sacraments had been practised by early Christians, refuting the protestant objections as simply historically incorrect. Similarly, it could be used to support the supremacy of the pontiff over the episcopal community (which became a dogma of Catholic religion in 1870). Basically, through Christian archaeology, historical materials were mobilized in defense of the temporal power of the Church and of its theological foundations.

In 1863 de Rossi founded a journal entitled Bullettino d'archeologia cristiana, in order to support the growth of the new discipline. De Rossi described the new discipline as 'an antidote given to us by the divine Providence to fight errors', and to prepare 'new triumphs of truth and faith'. De Rossi's main work, La Roma sotterranea cristiana, was published, in three volumes, between 1864 and $1877 . .^{50}$ Meanwhile, in September 1870, troops of the Italian army had occupied the territory formerly ruled by the pontiff, and had eventually entered Rome. The pontiff and the Roman 'aristocrazia nera' (black aristocracy - the legitimist families siding with the pontiff) retired into an indignant isolation, the windows of their palaces being closed and funereal draperies being exhibited. A message was sent from the pontiff to Catholics forbidding any sort of collaboration with the new - irreligious - Italian state.

If we now look back at the techniques adopted by Boncompagni in approaching the historical documents he was dealing with-mostly medieval manuscripts - it seems clear

49 Negro, op. cit. (47), 269.

50 The first series of Bullettino d'archeologia cristiana, published four times a year by Salviucci, ended in 1894, with the death of de Rossi. De Rossi's main work was La Roma sotterranea cristiana, descritta ed illustrata dal cav. Giovan Battista De Rossi, pubblicata per ordine della santità di n.s. Pio IX, 3 vols., Rome, 1864-77. The three volumes, rich in copperplates, were published by the Cromo-Litografia Pontificia, under the protection of the pontiff. 
that these were derived from the contemporary practice of disciplines such as epigraphy and philology, commonly employed as auxiliary to archaeology. Historical material regarding mathematics was handled following the rules dictated by the highly refined approaches that were flourishing in the dominant antiquarian culture. Consequently history of mathematics could be presented by its supporters as being as 'scientific' as the more recent archaeological disciplines - and its results could be presented as being as 'objective' as those of such disciplines. For this purpose, its methodology was shown to be similar to that of epigraphy, as a method characterized by the scrupulous, and allegedly neutral, study of ancient documents. Such a study was presented as self-contained, and no interest was shown for any sort of wider cultural synthesis that transcended the available documents. Through strict adherence to epigraphical techniques, the objects under study, namely the pieces of mathematical work, became an object of knowledge in the same way as archaeological objects were. They were meticulously described and catalogued and inserted in the wider historical reconstruction. In the case of mathematics, the panorama in which each single piece must find its place was that of a series of problems, to solve which specific problem-solving techniques had been elaborated. In the words of Bullettino contributor Francesco Siacci,

history of science can be reduced to a history of problems that have been presented and solved. Indeed, as a problem emerges, men try to solve it, pushed by their needs and by their pleasure. In this way a mental process of analysis begins, which yields - almost spontaneously - theorems, methods, theories and principles, in a word, science. ${ }^{51}$

In this perspective the task of the historian was limited to the reconstruction of the correct sequence of events, on the basis of the available historical documents. The historiographical work, according to Boncompagni and his collaborators, was structured on the model of archaeological discovery and classification. First of all a text was materially discovered, or rediscovered, in some ancient library. Then the text was transcribed and its original meaning restored. A scrupulous work of confrontation with other sources followed, in order to improve the knowledge of the biographical and bibliographical data. Research ended at this stage, with the registration of the new piece of information and, if the find had been particularly original, with the reassessment of a certain historical figure or his activity, or the way in which a certain piece of knowledge moved from one author to another. A paradigmatic case of such a process can be found in Boncompagni's presentation of the discovery and the publication of the Liber quadratorum, by Leonardo Pisano. ${ }^{52}$

In such an 'archaeological' perspective, Loria's remarks on Boncompagni's footnotes as being the real core of his work are confirmed and given a new meaning. The notes, the glosses to the original text, were indeed the essential part of the historiographical

51 F. Siacci, review of Philippe Gilbert, Étude historique et critique sur le problème de la rotation d'un corps solide autour d'un point fixe, in Bullettino (1878), 11, 217-56, 217.

52 This is a membranous manuscript of the fifteenth century, presently at the Biblioteca Ambrosiana in Milan. The text was believed to be lost by previous historians. See P. Cossali, Origine e trasporto in Italia, primi progressi in essa dell'algebra. Storia critica di nuove disquisizioni analitiche e metafisiche arricchita, 2 vols., Parma, 1797-9, i, 115 ; G. Libri, Histoire des sciences mathèmatiques en Italie, depuis le Renaissance jusqu'à la fin du dix-septieme siècle, 4 vols., Paris, 1838-44, ii, 27 and 40; M. Chasles, Aperçu historique sur l'origine et le developpemont des méthodes en géometrie, Paris, 2nd edn., 1875, 520 (first published in 1837). 
enterprise. The scrupulous glossing of ancient scientific texts was not seen as preliminary to a conceptual elaboration at some 'superior' level: it was in itself the crucial moment of the activity of the historian of science. What has been seen as Boncompagni's main shortcoming by later commentators was in fact the result of a clear methodological choice. It was a choice that shaped the entire production of the Bullettino. Our next step will be to assess on what grounds such a methodological choice was made.

\section{The ascetic mathematician}

A first answer to the question concerning the rationale behind the choice of the philological and archaeological methodology as the editorial line of the Bullettino has already emerged from the previous discussion of the prestige of antiquarian studies in Rome around the middle of the century. The assimilation of the history of the exact sciences into archaeological studies, and particularly into the new 'scientific' archaeology of de Rossi, was, however, just one possibility that Boncompagni saw to promote the discipline. By presenting history of mathematics as centred on the discovery and handling of ancient documents, and as mainly interested in the production of neutral, objective knowledge about specific and local historical events, Boncompagni managed to assimilate this discipline into the archaeological sciences. As we have seen, archaeological sciences enjoyed prestige and patronage in Rome, unlike other historical and philosophical studies.

Now, in addition to considering the 'constraints' that the cultural conditions of Rome set upon the methodology of the Bullettino, one can consider why, in the first place, a journal in the history of the exact sciences was conceived and realized there. We can approach this issue by considering the apologetic goals towards which traditional archaeology and, even more evidently, the new 'scientific' archaeology of de Rossi were oriented. In spite of the continuously repeated proclamations of neutrality and objectivity, after 1848 the scientific production of leading Roman archaeologists and epigraphists became more and more supportive of certain theological and political standpoints as the crisis of the temporal power of the Church deepened. In fact, the talk about 'scientific archaeology' only emerged as a major issue in Rome at precisely the time when archaeology was transformed into a most efficient weapon against theological enemies and, primarily, against the secularized thought of the liberal intelligentsia, which had taken the lead in Italian cultural life. Those who are unfamiliar with the heated debate between Italian liberal literati and the defenders of the temporal power of Rome can get an idea of its tone by looking at the poem A Satana (Hymn to Satan), written in 1863 by Giosué Carducci, a much celebrated poet and a father of the Italian nation. Satan, represented by an unstoppable locomotive, announces the near fall of the Roman theocracy, portrayed as the major enemy of social progress and of free thought in Italy. One strophe reads, 'It flashes and lightens/Girdled with flames/Matter, exalt thyself/Satan has won!'; and the conclusive strophes run, 'Hail to thee, Satan/Hail, the Rebellion/Hail, of the reason/The Great Vindicator/Sacred to thee shall rise/Incense and vows/Thou hast the god/Of the priests disenthroned ${ }^{.53}$

53 G. Carducci, 'A Satana' (1863), in Tutte le poesie, Rome, 1998, 233-8. The original version reads 
Let us now move back to the historiography of science. The emergence of the philological and scientific approach of Boncompagni can be related to the cultural struggle against the secularization of knowledge and society. A first hint pointing in this direction is offered by the many biographical reconstructions included in the Bullettino. The typology of these 'exemplary lives' shows a clearly defined ideological imprint. According to the Bullettino the scientist, and the mathematician in particular, is primarily an ascetic. Mathematical practice is indeed presented as entirely detached from the rest of cultural and social life. The mathematician pursues a pure, disinterested search for mathematical knowledge. Often the purity of such research is contrasted with the interests of those acting in more mundane spheres, like politics and administration. Indeed, the true mathematician is described as one who carefully avoids getting involved in debates over social issues. Let us consider a few examples from this set of apologetic biographies. We are told that the anti-Galileian Giovanni Antonio Magini (1555-1617) was 'entirely devoted to the practice of astronomy', so that he did not really take a relevant part in the 'war that at his time fervently opposed the supporters of the old theories and the innovators, which was mostly a theological and philosophical war'. ${ }^{54}$ In other words, real scientists do not mix themselves with such controversies, because they limit their interest to the strictly technical side of their work, without entering into extraneous - and dangerous - philosophical and moral questions. But we find more than that. The real scientist is also a religious man, one who manages to conciliate the use of reason with the strength of his own faith. This is the case with Augustin Cauchy (1789-1857), an exemplary figure of the mathematician, on whom Boncompagni himself wrote a long biographical piece. "While he was at the Polytechnic School', Boncompagni wrote,

he always behaved as a sincere Christian: he was devout and he was benevolent and kind towards his own fellows. One could see him on his knees, by his bed, reciting devotedly his usual prayers amidst the general indifference; but his fellows never disturbed him, as his extraordinary merit imposed respect. ${ }^{55}$

And, later on, 'Cauchy returned to France in 1838, aiming to remain out of the political

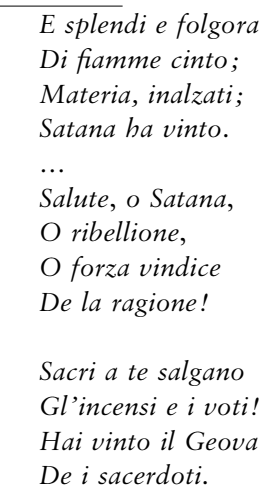

54 F. Jacoli, review of A. Favaro (ed.), Carteggio inedito di Ticone Brahe, Giovanni keplero e di altri celebri astronomi e matematici dei secoli XVI e XVII con Giovanni Antonio Magini, tratto dall'archivio Malvezzi de' Madici in Bologna, in Bullettino (1887), 20, 37-94, 42.

55 B. Boncompagni, review of C.-A. Valson, La vie et les travaux du Baron Cauchy, membre de l'Academie des Sciences, in Bullettino (1869), 2, 1-95, 10. 
events, and to keep faith to his personal convictions. Study, domestic life and charity were to occupy, from then onwards, each moment of his life' ${ }^{56}$ The association of scientific activity with religious devotion is justified, in this piece, by referring to the argument that the virtues associated with a pure faith are precisely the virtues that improve the possibility of success for the scientist. 'Simplicity and modesty', wrote Boncompagni, 'are a remarkable aspect of true scientific knowledge'. They 'derive from the feeling of weakness and limitation proved by man when he contemplates the wonders of creation, and the immense territories open to his intellect'. ${ }^{57}$ The humility of the believer is exalted as it functions as a moderating factor in the use of reason. The virtue of humility is opposed to the vice of pride, which is proper to those who try to make sense of the universe without referring to its original cause-God himself. So, in the biographical note devoted to Sebastiano Purgotti (1799-1879), we are told that he 'did not reject the dogma because of the subtleties of reason', and that he 'took as the theoretical basis of any knowledge the idea of the unity of God and that of the immortality of the soul'. In fact, in Purgotti one finds both 'doctrine' and 'sincere attachment to the Catholic truths', so that he was able to solve philosophical questions about God, man and the world 'in a way that was perfectly harmonious with religious truth'.$^{58}$

Not surprisingly, apologetic descriptions of the lives of mathematicians who were members of the Church are numerous in the Bullettino. One reads that the Piarist mathematician Giovanni Antonelli (1818-72) 'ended his life with the serenity proper of a pure and Christian soul' 59 and that the 'taciturn' Jesuit Nazareno Mancini, professor of mathematics and assistant of Angelo Secchi at the Osservatorio Pontificio del Collegio Romano, was also devoted to the 'spiritual education' of those who followed his mathematical courses. ${ }^{60}$ Another of Angelo Secchi's assistants, the Jesuit astronomer Paolo Rosa, was known since his college years 'for his exemplary life and the purity of his costumes'. Such a 'flower of virtue and purity', one reads in his obituary, 'could not remain amidst the uncultivated field of the world'; clearly 'the Lord had planned to transplant him in the closed gardens of Religion ${ }^{6}{ }^{61}$ But let us go back to the biographies of secular mathematicians. Invariably, the virtues of humility and charity and the strength of their faith are underlined. One reads that Michel Chasles (1793-1880) 'provided comfort to many suffering people, offering them generous help'. ${ }^{62}$ Herman Grassmann (1809-77) is described as interested in positive theology and as the author of an essay entitled On the Decline of Faith. ${ }^{63}$ On Hermann Hankel (1839-73), who was also a collaborator of the Bullettino, one reads that he admired 'the highest achievements of the human spirit in the

56 Boncompagni, op. cit. (55), 30.

57 Boncompagni, op. cit. (55), 3-6.

58 A. Stiattesi, 'Intorno alla vita ed ai lavori di Sebastiano Purgotti', Bullettino (1883), 16, 619-72, 639.

59 A. Stiattesi, 'Intorno alla vita ed ai lavori del P. Giovanni Antonelli delle Scuole Pie', Bullettino (1872), 5, 253-66, 265.

60 F. Marchetti, 'Cenni necrologici del P. Nazareno Mancini’, Bullettino (1870), 3, 429-30, 430.

61 F. Marchetti, 'Intorno alla vita ed ai lavori del P. Paolo Rosa', Bullettino (1875), 8, 305-6.

62 B. Boncompagni, 'Michele Chasles', Bullettino (1880), 13, 815-68, 824.

63 A. Favaro, 'Della vita e degli scritti fisico-matematici di Ermanno Grassmann', Bullettino (1878), 11, 699-756, 702; Victor Schlegel, Hermann Grassmann, Sein Leben und Werke, Leipzig, 1878, 1-15. 
field of the mathematical sciences', and that because of his profound moral sense, he remained 'solidly linked to the revealed truths of Christianity for his entire life, in spite of the contrary trend of the period ${ }^{64}$ When it comes to renowned irreligious mathematicians, uneasiness is evident. Such is the case of Charles Henry, who cautiously introduced his essay on Condorcet by remarking, 'we will present the facts without expressing any judgement. The reader interested in having an opinion about the character and the life of the old perpetual secretary of the Academy of the Sciences can turn to his political and literary works'. ${ }^{65}$

To conclude this part on the exemplary lives of mathematicians, it can be noted that Boncompagni's life itself was described as perfectly fitting such an idealized figure of the Catholic man of science. He was remembered by his colleagues as a deeply devout Catholic, conducting an isolated and hardly mundane life, completely absorbed as he was in his erudite studies, his editorial activity and his religious practices ('of which he was a very zealous observer $\left.{ }^{66}\right)$. At the Accademia Pontificia dei Nuovi Lincei, Boncompagni was remembered for his unusual humility in dressing and behaving, for his 'serious expression' and for his 'thoughtful gaze'. We are also told that he 'refused the most attractive propositions of marriage' and that 'he never bought a carriage for himself'. This, one should remember, while he was generously financing charities, his mathematical library and the activity of his own printing office. ${ }^{67} \mathrm{~A}$ biographer remarked that Boncompagni 'came to the assistance of needy scholars and students, assigning them to well-paid tasks in transcription and in translation, thus leaving behind him the memory of an enlightened and generous patronage ${ }^{6}{ }^{68}$ It is particularly worth noting that Boncompagni went through the crucial date of 1870 without any apparent involvement in the events that were changing the destiny of Rome and its ruling classes. So Antonio Favaro, in 1894, described his old friend and maestro Boncompagni as one eminently uninterested in politics. According to Favaro, 'the political upheavals taking place during his life did not have any influence on him'; and the fact that he did not adhere to 'the new order instituted in Rome on 20 September 1870 did not imply his will to return to the ancient state of things' ${ }^{69}$ We have no reasons to doubt that Boncompagni avoided any direct involvement in Roman political life. But it would be certainly misleading to conclude that Boncompagni did not in fact play a crucial role in the ideological battle fought by the Roman Curia and by the Roman legitimist aristocracy against the new Italian state and, more generally, against the secularization of knowledge and society.

64 W. von Zahn, 'Commemorazione di Ermanno Hankel', Bullettino (1876), 9, 290-6, 292.

65 'Nous venons d'exposer les faits, sans aucune appréciation. Le lecteur désireux de se faire un avis sur le charactère et la vie de l'ancien secrétaire perpétuel de l'Académie des Sciences, ne saurait mieux fire que de recourrir à ses ouvrages politiques et littéraires'. C. Henry, 'Sur la vie et les écrits mathématiques de JeanAntoine-Nicolas Caritat Marquis de Condorcet', Bullettino (1883), 16, 271-82, 272.

66 A. Favaro, 'Don Baldassarre Boncompagni e la storia delle scienze matematiche e fisiche', Atti del Regio Istituto Veneto di Scienze, Lettere e Arti (1894-5), 6, 509-21, 520.

67 I. Galli, 'Elogio del Principe Baldassarre Boncompagni', Atti dell'Accademia Pontificia dei Nuovi Lincei (1894), 47, 40-5.

68 E. Carruccio, 'Baldassarre Boncompagni', in Dictionary of Scientific Biography (ed. C. Gillispie), New York, 1981.

69 Favaro, op. cit. (17), 520-1. 


\section{In defence of the traditional hierarchy of knowledge}

Let us put the question of Boncompagni's ideological battle in perspective. The attempt to conciliate faith and individual reason, the authority of Rome and modern scientific research, was certainly nothing new. In this respect the editorial line of the Bullettino was supporting what was already a well-structured theoretical position. The relation between the dogmas of revealed religion and modern scientific thought had indeed become a crucial issue in the aftermath of the French Revolution, when Catholic intellectuals elaborated their response to the modernization of society and to the secularization of knowledge. This was not merely a rejection of 'rationalistic' criticisms. In the case of mathematics, for instance, one can think of the research conducted in the early nineteenth century by mathematicians such as Paolo Ruffini (1765-1822) in Modena, by Gabrio Piola (1791-1850) in Milan or Nicola Fergola (1753-1824) in Naples. These devout mathematicians tried, from different perspectives and with different methodologies, to conjugate the latest development of the mathematical sciences with the apologetic use of this form of knowledge. In their writings Catholicism is far from being hostile to the progress of modern science; it is presented rather as its main ally in the search for scientific truth. It was a strategy by which the agnosticism traditionally associated with modern science could be overcome in the name of scientific methodology itself. A similar strategy was later to characterize the work of remarkable Jesuit scientists such as astronomer and astrophysicist Angelo Secchi (1818-78), director of the Observatory of the Collegio Romano and protégé of Pius IX, who was almost the same age as Boncompagni, was his personal friend and was an occasional collaborator on the Bullettino.

At the institutional level, the attempt to harmonize scientific research and the dogmas of Catholicism was the primary task of a specific academy: the Accademia di Religione Cattolica (ARC), founded in Rome in the aftermath of the traumatic experience of the Roman Republic (1798-9) by some erudite ecclesiastics, under the protection of Pius VII. Members of the academy came from various disciplines, particularly from the natural and mathematical sciences; the mathematicians quoted above as examples of devout scientists were in fact all invited to participate in its reunions. Interestingly, in 1844 the academy asked Boncompagni to join the others in the effort to resist the secularization of scientific knowledge and the collapse of the traditional hierarchy of knowledge. Boncompagni, one will remember, had just published his mathematical memoir in the journal directed by Crelle. The very same day, the Jesuit philosopher Luigi Taparelli d'Azeglio was also nominated a member of the academy. The conjunction of a neo-scholastic thinker and Boncompagni is interesting, and far from being coincidental, as we will soon realize. As for the activity of the academy in the middle of the century, it was centred on a series of apologetic themes regarding the beneficial influence of Christianity 'upon every dimension of civilization'. The fundamental goals of the academy, as expressed in its statutes, were those of 'defending the dogmas of Catholic religion', and 'fighting the errors which are attacking it' ${ }^{70}$ The intellectual resources for this immense fight were mostly found in the medieval scholastic tradition, the rediscovery and valorization of which began precisely in

70 On the Accademia di Religione cattolica see A. Piolanti, L'Accademia di Religione Cattolica, profilo della sua storia e del suo tomismo, Vatican City, 1977. Quotes are from page 212. 
the central years of the nineteenth century. In particular, neo-Thomism emerged in the 1850s and 1860s as the official philosophical and theological perspective of the Catholic Church, a position which was confirmed by the decrees of the first Vatican Council (1869-70) and which was actively supported by Pius IX and by his successor Leo XIII (r. $1878-1903) .{ }^{71}$

With respect to the natural and mathematical sciences, the ARC supported an empirical and experimental conception, which was presented as essentially derived from Galileo's writings. Early versions of such an approach, which could be defined as 'apologetic empiricism', were characterized by a very cautious employment of reasoning that tended to generalize local experiences and by a widespread dislike for any process of abstraction from the phenomenological level; conceptual syntheses were indeed portrayed as potentially dangerous for healthy empirical work. In the mathematical sciences this implied stressing the specific and local nature of any kind of technique or problem-solving procedure.

As I have argued elsewhere, this phenomenological, 'local' approach to science was functional for a more general cultural strategy that aimed to restore a hierarchical order among scientific, moral and religious sciences. ${ }^{72}$ Such a strategy culminated - in the midnineteenth century - in the choice of neo-scholasticism as the new legitimate conceptual framework of Catholic thought. An academic from the ARC noted, in 1881, that 'it is precisely this hierarchy of all sciences, presented with clarity and precision' that really matters in the texts of Thomas Aquinas. Such a structure of knowledge was the real foundation of the medieval civilization, where 'all disciplines were harmonized around theology, by means of philosophy'. But the harmonious medieval synthesis came under attack, as did its structure of knowledge, particularly in the eighteenth century. The academic continued,

you know all too well, gentlemen, how they dared to attack and break down that scientific synthesis; how an intemperate and haughty analysis tried to separate science and faith, literature from the arts, the State from the Church. But you also know that illustrious men fought against this despicable separation.

The mission of the members of the academy was thus stated as that of 'restoring the highest and noblest philosophy, showing its harmony with faith, and to let this harmony descend on literature, arts, and costumes, that is, on every man's and every country's life'. Thanks to their efforts, 'philosophy and natural sciences, after having progressed so much, will render homage to theology, which will offer them splendour and strength in exchange for their support'. ${ }^{73}$

71 On the actions taken by Pius IX in order to promote neo-scholastic thought among Catholic scholars, see A. Piolanti, Pio IX e la rinascita del tomismo, Vatican City, 1974. A crucial document of the pontificate of Pius IX was the Syllabus Errorum (1864), where eighty 'erroneous' propositions are listed, including one stating that 'human reason, without any reference whatsoever to God, is the sole arbiter of truth and falsehood, and of good and evil' (prop. 3); that theology lies on the same plane as the natural sciences (props. 8 and 9); that Catholic doctrine opposes true scientific progress (prop. 12); and that State and Church should be separated (prop. 55). As for Leo XIII, in the first year of his pontificate he promulgated the encyclical Aeternis Patris (1879), a real manifesto for the restoration of the 'Christian philosophy', i.e. neo-Thomism.

72 M. Mazzotti, 'The geometers of God: mathematics and reaction in the Kingdom of Naples', Isis (1998), 89, 674-701.

73 Quoted in Piolanti, op. cit. (70), 492-3. 
The Catholic intelligentsia grouped in the ARC fought to restore a scholastic hierarchy among different forms of knowledge. Boncompagni's entire production, and the methodological perspective he chose for the Bullettino, can be best understood as part of such an ambitious cultural project. This project indeed sheds light upon characteristic features of the Bullettino such as its pseudo-Galileian experimentalism and phenomenalism, its local conception of mathematical procedures, the rejection of the 'dogma' of materialism and the rediscovery of the Middle Ages as a period of unsurpassed cultural flourishing. ${ }^{74}$ Avoiding the openly apologetic use of the exact sciences made by some Catholic mathematicians of the restoration (which included mathematical 'proofs' of the existence of God and the immateriality of the soul), the Bullettino managed authoritatively to support a historiographical methodology that neutralized the potentially subversive charge attributed to modern physical and mathematical sciences. Their development was indeed framed in a continuous refinement of mathematical techniques, but not one associated with relevant conceptual changes. This closure of the mathematical sciences within their own technical dimension and their isolation from other branches of human knowledge and action were functional to their being inserted into the neo-scholastic structure of knowledge, which characterized Catholic official culture from the midnineteenth century onwards. It characterized, for instance, the works - and the very institutional structure - of the Accademia Pontificia dei Nuovi Lincei, the new academy of the sciences founded by Pius IX in 1847 in order to improve scientific research in Rome, through the appropriation of the prestigious heritage of the ancient Accademia dei Lincei. Its founding members were thirty well-known scientists, including Angelo Secchi, Barnaba Tortolini, Domenico Chelini and Boncompagni himself. It is significant that the academy had only one class, that of physical and natural sciences; moral and philosophical sciences were not considered matters to be investigated by a scientific academy.

In 1870, two years after the first number of the Bullettino had appeared, Rome fell into the hands of the Italian army. The town was eventually overcome by that trend of secular culture that had been the declared enemy of the champions of the ARC. Shortly after the occupation of Rome, the Italian government asked for a new class of moral and philosophical sciences to be introduced in the Accademia Pontificia dei Nuovi Lincei. As a consequence the president of the academy, Benedetto Viale-Prelà, physician of the pontiff, together with a group of academics who did not recognize the legitimacy of Italian rule, abandoned the assembly. In 1871, while the academics favourable to the new state of things renamed their academy Accademia Nazionale dei Lincei, those who opposed the secularization of state and culture reunited under the previous name of Accademia Pontificia dei Nuovi Lincei. ${ }^{75}$ Boncompagni was among them, and offered his printing office and his resources to guarantee the publication of the acts of the academy. In the same year, Boncompagni refused the offer made by the Italian Prime Minister Quintino Sella of a seat in the parliament of the Kingdom of Italy. This episode is interesting not only

74 Anti-materialist claims are most typical of the contributions of the Jesuit scientists close to Angelo Secchi. See, for instance, N. Mancini, review of A. Farnocchia, Corso elementare completo di matematiche pure, in Bullettino (1869), 2, 279-98, 279; and Stiattesi, op. cit. (58), 641.

75 On this episode see R. Morghen, L'Accademia nazionale dei lincei nel CCCLXVIII anno dalla sua fondazione, nella vita e nella cultura dell'Italia unita (1871-1971), Rome, 1972. 


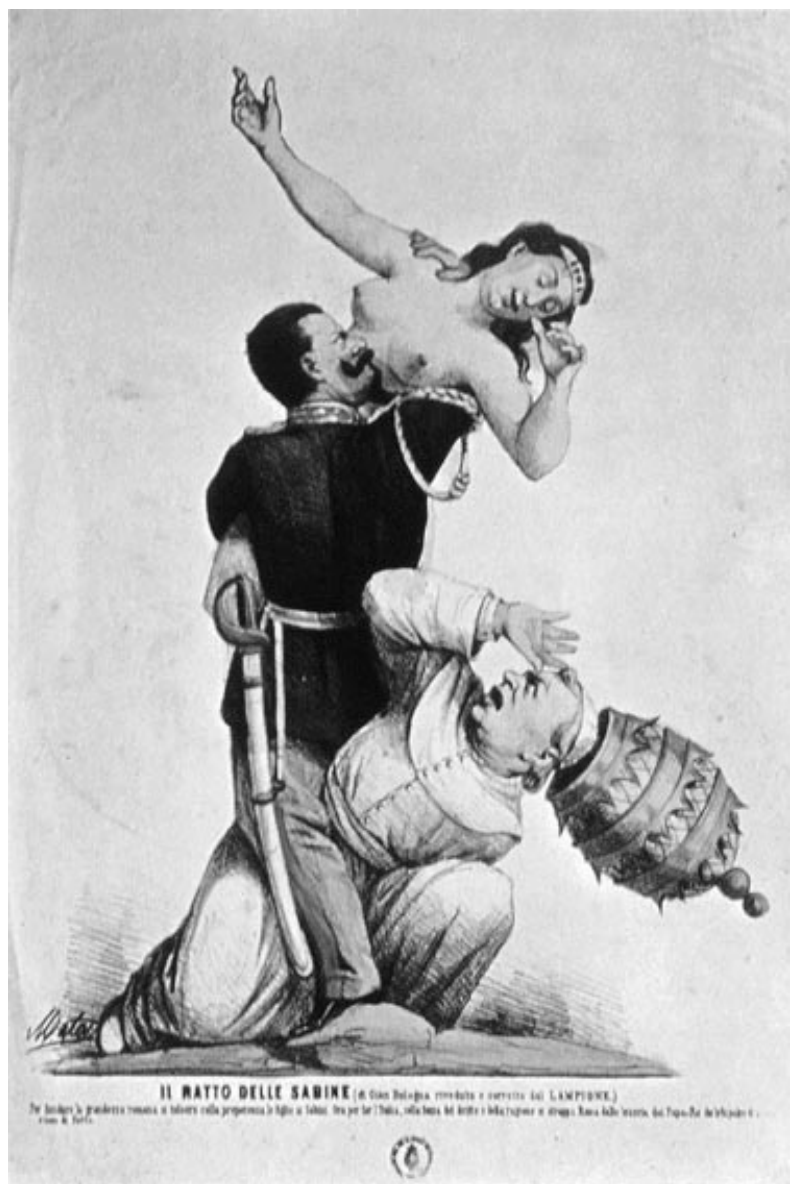

Figure 3. Vittorio Emanuele II, King of Italy, pulls Rome away from the arms of Pope Pius IX (from Il Lampione).

because it confirms Boncompagni's political convictions, but also because it allows us to sketch, through the emblematic figure of Quintino Sella, an image of scientific knowledge which was antithetical to Boncompagni's. We can therefore conclude our study with the presentation of this secularized conception, against which the efforts of most of the Bullettino's contributors were in fact oriented.

In the years following the political unification of Italy in 1861, a remarkably high number of scientists, and particularly mathematicians, actively participated in the government of the country. Prime Minister Quintino Sella himself was a scientist, and indeed he was to be elected president of the Accademia Nazionale dei Lincei in 1874. The idea of asking Boncompagni to enter the parliament made sense, given the prestige of the prince, which was not only linked to his rank but also to his distinguished career in the history of science. But the conception of science, and of history of science, defended by Boncompagni could not be further from that of Sella and his fellow scientists working at the political and 
cultural organization of the Italian state. As we have seen, in the Bullettino the scientist was described as one isolated from the rest of human activities and completely absorbed by his speculative research. This scientist was also devout, which provided him with those virtues necessary to conduct successfully scientific research. Sella and the community that he represented referred to the opposite image of the scientist-patriot, who employs his knowledge effectively to construct a new model of society, based on rational and secular grounds. As a matter of fact, most of the Italian mathematicians active in the 1870s had in some way contributed to the creation of the new nation: fighting in the independence wars of the 1850s, entering the commissions for the reform of education and even being elected as members of the new parliament. One can think of the patriotic and liberal convictions of leading mathematicians such as Francesco Brioschi (1824-97), Enrico Betti (1823-92), Luigi Cremona (1830-1903), Felice Casorati (1835-90) and Eugenio Beltrami (1835-1900). Note also that Brioschi and Betti became members of the Consiglio Supremo della Pubblica Istruzione (Supreme Council of Public Education), Beltrami entered the parliament and Cremona reached the position of Minister of Public Education. ${ }^{76}$ These scientists conceived of political action as a continuation of their scientific activity. In their eyes, scientific advancement was a necessary component of the Risorgimento (resurgence) of the Italian nation after centuries of political and cultural decline. Far from being separate spheres, political action and cultural reform were essentially linked in the process of modernization of the country. Politically, the model to be followed was that of the liberal constitutional monarchy, whereas the university system should be rebuilt on the model of the German one, under the unifying perspective offered by positivistic philosophy. Such achievements were regarded as necessary in order to reach the goals of economic modernization and industrialization, around which the consensus of the great bourgeoisie of the country had been consolidated.

The journals around which the emerging Italian mathematical community had grouped were the Annali di matematica pura e applicata (founded in 1858), the first journal of mathematics which could properly be defined as 'Italian', and the Giornale di matematiche (founded in 1863), edited by Giuseppe Battaglini (1824-94) in Naples and addressed specifically to university students. The main goals of these periodicals were to update mathematical research and teaching and, at the same time, to bring the original works of the Italians to the attention of the international community. As a consequence, historical considerations were not a primary interest, and they did not find much space in these periodicals, apart from questions relating to contemporary issues, such as the adoption of textbooks or questions of historical priority. In 1898 a new journal appeared entirely devoted to the history of mathematics, the Bollettino di bibliografia e storia delle scienze matematiche, edited by Gino Loria (1862-1954). Far from being a continuation of Boncompagni's Bullettino, which had ceased publication in 1887 , the new journal embodied very different historiographical principles. Loria referred to Boncompagni as his main source of inspiration, presenting his historiographical innovations as 'some necessary formal modifications' ${ }^{77}$ In fact, major changes are evident. First of all, the bibliographical

76 On the participation of mathematicians to the political and cultural life of the Italian state after 1861, see Umberto Bottazzini, $\mathrm{Va}$ ' pensiero. Immangini della matematica dell'Italia dell'Ottocento, Bologna, 1994.

77 G. Loria, Scritti, conferenze, discorsi sulla storia della matematica, Padova, 1937, 31. 
apparatus and the famously overlong footnotes - central to Boncompagni's methodology - were drastically reduced in Loria's journal. Second, interest shifted decidedly away from the medieval period in favour of the modern age. This was because topics were now chosen that related to issues arising from university courses of mathematics and engineering, the objective being to clarify the origin of contemporary concepts to students. The focus was no longer the handling of manuscript material but rather the didactical value of the history of mathematics as a tool useful to a better understanding of contemporary issues. Third, the character of the journal was clearly national, as opposed to the programmatically international nature of Boncompagni's Bullettino. The new journal was addressed specifically to the Italian community of professors and students; emblematically, contributions were almost invariably written in Italian. As has been remarked, Loria's historiographical approach was in tune with the goals and the interests of the Italian mathematical community of the late nineteenth century $;^{78}$ by contrast, Boncompagni's erudite and antiquarian approach could not but appear foreign to such a tradition. Abandoned in Italy, the methodological model elaborated by Boncompagni influenced certain foreign periodicals, such as the Bibliotheca Mathematica, founded in 1884 by the Swedish mathematician Gustaf Eneström (1852-1923).

The clash between the secularized, liberal and nationalistic culture of the leading Italian mathematicians and the antiquarian culture that had nourished the enterprise of the Bullettino became unavoidable in 1870. As Rome was occupied, the historian Mommsen asked Prime Minister Sella what would be the founding value on which the 'third Rome' (the secular capital of the Italian state) was to be founded. Sella replied, pointing at the universal value of science,

we take science to be our supreme duty in Rome. ...Italy has a debt to the rest of mankind; it must offer its contribution to the discovery of truth as it appears - incontestable - from scientific investigation. Put out the lights! Electrical spots, this is what we want!

Sella had an openly hostile position towards both the temporal power and the cultural hegemony of the Church. He had been, among the politicians, 'the most impatient promoter of the military occupation of Rome'. He wrote that 'as empirical science advances, God must necessarily retire' ${ }^{79}$ The cultural enterprise that had inspired and shaped the Bullettino offered no possibility of compromise with the secularized culture of the century he represented. This culture, and its image of science, was foreign not only to Boncompagni, but also to most of the contributors to the Bullettino, starting, naturally, with the Jesuit astronomers and mathematicians linked to Angelo Secchi. But think also of Timoteo Bertelli, scholar of medieval mathematics, pioneer of seismology and of studies on telecommunications: he himself was a Barnabite priest, a member of the ARC and the future president of the Accademia Pontificia dei Nuovi Lincei (1895). Or, again, consider that the geometer Domenico Chelini (1802-78), well known in his day for his studies of rational mechanics, was a Piarist priest and left the University of Rome in 1870 in protest

78 See L. dell'Aglio, 'Des glissements dans 1'historiographie des mathématiques: le cas du Bollettino di bibliografia e storia delle scienze matematiche de Gino Loria', in E. Ausejo and M. Hormigon (eds.), Messengers of Mathematics: European Mathematical Journals (1800-1946), Madrid, 1993, 283-97.

79 Quotes are from P. di Mattei, 'P. Angelo Secchi e Quintino Sella', in Padre Angelo Secchi nel centenario della morte (1878-1978), Rome, 1979, 67-8. 
against the Italian occupation of the town. Similarly, some of the most significant foreign contributors were opposing the secularization of the sciences. Think of Hermann Hankel, or of Paul Mansion (1844-1919) professor of mathematics at the University of Ghent, editor (1881-1910) of the journal Mathesis, but also translator of Dante and of Cardinal Edward Henry Manning - the strenuous defender of the temporal power of the Church and of the 'principle of authority' at the first Vatican Council (1869-70).

\section{Conclusion}

Historians of science, in the last decades, have fruitfully focused on the cultural and social shaping of scientific knowledge. As a matter of fact, such a methodological move has been less evident in the case of mathematics. The present study aims to be a contribution in this direction, based on the assumption that mathematical knowledge does not differ in any essential way from other forms of knowledge, and that the study of its production and diffusion should be carried out using similar methodological tools to those employed in the history of other sciences.

In this study, I have argued that the innovative features of the Bullettino, both in its format and in its contents, are best understood with reference to the specific historical and cultural contingencies that accompanied the life of the periodical. As the fall of the temporal power of the Church became imminent, all intellectual resources were mobilized against the secularization of moral, political and scientific knowledge. The technical conception of the mathematical sciences and the 'archaeological' conception of their history were subservient to the general argument that individual reason must be subject to the superior sphere of religious authority. Although innovative in opening a space entirely devoted to the history of the exact sciences, Boncompagni's Bullettino adopted a historiographical methodology elaborated by scholars who resisted the complete secularization of knowledge. Boncompagni's methodological choices, usually described as extremely 'technical', philosophically 'neutral' and even 'positivistic', were in fact organically connected to the neo-scholastic conception of knowledge. The apologetic dimension of Boncompagni's methodology is not immediately evident, particularly if it is detached from its wider conceptual framework. As a consequence, historians have been puzzled by the formal peculiarities, the eccentric editorial choices and - in the end - by the extraneousness of the Bullettino with respect to the rest of contemporary Italian scientific and mathematical culture. As we have seen, however, it is precisely the opposition to such culture that characterizes the anti-modern battle of the Bullettino. 